\title{
Expression of Type II cGMP-dependent Protein Kinase in Rat Kidney Is Regulated by Dehydration and Correlated with Renin Gene Expression
}

\author{
Stepan Gambaryan, ${ }^{\star}$ Christoph Häusler, ${ }^{\star}$ Tilman Markert, ${ }^{\star}$ Doris Pöhler, ${ }^{\star}$ Thomas Jarchau, ${ }^{\star}$ Ulrich Walter, ${ }^{\star}$ Winfried Haase, ${ }^{\ddagger}$ \\ Armin Kurtz, ${ }^{\S}$ and Suzanne M. Lohmann* \\ *Medizinische Universitäts-Klinik, Klinische Biochemie and Pathobiochemie, 97080 Würzburg; ${ }^{\ddagger}$ Max-Planck-Institut für Biophysik, \\ 60596 Frankfurt am Main; and ${ }^{\S}$ Institut für Physiologie I, Universität Regensburg, 93053 Regensburg, Germany
}

\begin{abstract}
cGMP-based regulatory systems are vital for counteracting the renin-angiotensin system (RAS) which promotes volume expansion and high blood pressure. Natriuretic peptides and nitric oxide acting through their second messenger cGMP normally increase natriuresis and diuresis, and regulate renin release; however, the severe pathological state of cardiac heart failure is characterized by elevated levels of atrial natriuretic peptide that are no longer able to effectively oppose exaggerated RAS effects. There is presently limited information on the intracellular effectors of cGMP actions in the kidney. Recently we reported the cloning of the cDNA for type II cGMP-dependent protein kinase (cGK II), which is highly enriched in intestinal mucosa but was also detected for the first time in kidney. In the present study, cGK II was localized to juxtaglomerular (JG) cells, the ascending thin limb (ATL), and to a lesser extent the brush border of proximal tubules. An activator of renin gene expression, the angiotensin II type I receptor inhibitor, losartan, increased cGK II mRNA and protein three to fourfold in JG cells. In other experiments, water deprivation increased cGK II mRNA and protein three to fourfold in the inner medulla where both cGK II, and a kidney specific $\mathrm{Cl}^{-}$ channel shown by others to be regulated by dehydration, are localized in the ATL. Whereas additional data suggest that cGK I may primarily mediate cGMP-related changes in renal hemodynamics, cGK II may regulate renin release and ATL ion transport. (J. Clin. Invest. 1996. 98:662-670.) Key words: atrial natriuretic peptide $\bullet$ nitric oxide $\bullet$ losartan $\bullet$ renin secretion $\bullet$ chloride transport
\end{abstract}

\section{Introduction}

Certain of the profound effects of two major signal transduction systems, atrial natriuretic peptide $(\mathrm{ANP})^{1}$ and endothelium-derived relaxing factor (EDRF) or nitric oxide (NO), on the cardiovascular and renal systems are mediated by cGMP (1). cGMP effects can be mediated by a number of effectors in-

Address correspondence to Dr. Stepan Gambaryan, Medizinische Universitäts-Klinik, Klinische Biochemie und Pathobiochemie, Josef Schneider Str. 2, 97080 Würzburg, Germany. Phone: 49-931-201-3137; FAX: 49-931-201-3153.

Received for publication 19 February 1996 and accepted in revised form 3 June 1996.

J. Clin. Invest.

(C) The American Society for Clinical Investigation, Inc.

0021-9738/96/08/0662/09 \$2.00

Volume 98, Number 3, August 1996, 662-670 cluding cGMP-gated channels, cGMP-regulated phosphodiesterases, cGMP-dependent protein kinases (cGK), and at high cGMP concentrations, possibly cAMP-dependent protein kinases (cAK). Mammalian cGK exists as two major forms, cGK I and cGK II, which have been cloned and defined as products of two separate genes (reviewed in references 2, 3). cGK I is expressed at high levels in cerebellar Purkinje cells and human platelets, moderately in vascular smooth muscle cells, and at lower levels in cardiac myocytes (3). cGK I has been shown to lower intracellular $\mathrm{Ca}^{++}$, and to inhibit vascular smooth muscle contraction (4), platelet activation (5), and endothelial cell permeability (6), thereby opposing events leading to hypertension, thrombosis, and atherosclerosis. In contrast, cGK II has not been detected in cells of the cardiovascular system; rather, it is most highly concentrated in the brush border of the intestinal mucosa (7) and appears to mediate cGMP stimulation of $\mathrm{Cl}^{-}$secretion by the cystic fibrosis transmembrane conductance regulator (CFTR) channel (8). However, in addition to intestinal mucosa, cGK II has also recently been demonstrated in brain and kidney (2).

Substances which increase cGMP, such as ANP, NO, and small renal peptides like urodilatin, as well as cGMP itself, have multiple effects on kidney function, Renal actions of ANP include afferent arteriole dilation and efferent arteriole constriction, increase in glomerular capillary hydraulic pressure resulting in increased glomerular filtration rate, inhibition of angiotensin II-stimulated fluid reabsorption in the proximal tubule (PT), and inhibition of water and sodium reabsorption by medullary collecting duct cells (9). Furthermore, ANP, NO, and cGMP regulate renin secretin $(9,10)$, and NO mediates vasodilation of the afferent arteriole in response to tubuloglomerular feedback of the macula densa (11). In general, cGMP counteracts the effects of vasoconstrictors and activators of salt and fluid retention, and thus constitutes an important counterregulator of hypertension and the renin-angiotensin system $(12,13)$. However, information concerning the mediators of cGMP action in kidney is fragmentary. A cGMP-gated channel has been cloned from bovine kidney (reviewed in reference 14), and cGMP-inhibited phosphodiesterases have been found in renal vascular smooth muscle cells and in cortical and outer medullary collecting ducts (15). cGK I has been previously localized in kidney only in contractile elements, in-

1. Abbreviations used in this paper: AA, afferent arteriole; ANP, atrial natriuretic peptide; ATL, ascending thin limb; $\mathrm{AT}_{1} \mathrm{R}$, angiotensin II type I receptor; cAK, cAMP-dependent protein kinase; CCD, cortical collecting duct; CFTR, cystic fibrosis transmembrane conductance regulator; cGK, cGMP-dependent protein kinase; $\mathrm{CHF}$, congestive heart failure; DTL, descending thin limb; EDRF, endothelium-derived relaxing factor; IMCD, inner medullary collecting duct; JG, juxtaglomerular; PCT, proximal convoluted tubule; PT, proximal tubule; RAS, renin-angiotensin system; TAL, thick ascending limb. 
cluding vascular smooth muscle cells, mesangial cells and contractile interstitial cells (16), suggesting that cGK I may mediate cGMP effects on hemodynamics and thereby glomerular filtration rate. In the present study we addressed the question of the localization and regulation of endogenous cGK II, and the relationship of cGK II to reported effects of cGMP in the kidney. cGK II was localized to the brush border of the proximal tubule, juxtaglomerular (JG) renin-secreting cells, and the ascending thin limb (ATL) of Henle's loop. Inhibition of the type I angiotensin II receptor $\left(\mathrm{AT}_{1} \mathrm{R}\right)$ stimulated the level of both renin and cGK II expression in JG cells, suggesting a potential involvement of cGK II in renin regulation. Water deprivation, which has been shown to increase the level of a kidneyspecific $\mathrm{Cl}^{-}$channel CIC-K1 (17), also increased cGK II mRNA and protein in the inner medulla, suggesting that in kidney, as in intestine (7), cGK II may play an important role in regulation of $\mathrm{Cl}^{-}$transport.

\section{Methods}

Western blot analysis. Tissues used for Western blots and all other analyses were obtained from male Sprague Dawley rats (150-200 g) anaesthetized with nembutal. Whole kidney, as well as the different kidney zones, were homogenized in PBS containing protease inhibitors $(5 \mu \mathrm{g} / \mathrm{ml}$ leupeptin, $1.5 \mathrm{mM}$ benzamidine, $200 \mathrm{U} / \mathrm{ml}$ aprotinin, $2 \mu \mathrm{g} / \mathrm{ml}$ pepstatin A, $10 \mu \mathrm{g} / \mathrm{ml} \mathrm{PMSF}$, and $1 \mathrm{mM}$ EDTA). Samples were analyzed by Western blot using affinity-purified cGK II antibody diluted 1:400, or cGK I antiserum diluted 1:600, and $1 \mu \mathrm{Ci}^{125}$ I-protein A.

Northern blot analysis. Total RNA was extracted using RNAzol B (Wak-Chemie, Bad Homburg, Germany) based on the method of Chomczynski and Sacchi (18) and subsequently poly(A) RNA was prepared using an mRNA purification kit (Pharmacia-LKB, Freiburg, Germany). Northern blots were hybridized with ${ }^{32}$-P-labeled antisense RNA probes made by in vitro transcription from pGKII5-5, containing bp 741-1450 of the cGK II sequence (2), and were washed at $70^{\circ} \mathrm{C}$ with $2 \times \mathrm{SSPE} / 0.1 \%$ SDS and subsequently with $0.1 \times \mathrm{SSPE} / 0.1 \%$ SDS.

Immunocytochemistry. After cannulation of the rat aorta below the level of the kidneys, kidneys were perfused with $4 \%$ paraformaldehyde in PBS and used for making all tissue sections. Frozen kidney sections $(5 \mu \mathrm{m})$ were prepared from 10 different rats, mounted on silane-coated glass slides, and incubated with affinity-purified antiserum against cGK II (diluted 1:200) or antiserum against cGK I (diluted 1:2,000) overnight. Antibody production and purification were described previously (7). Labeling was performed using a peroxidase coupled anti-rabbit antibody (Dianova, Hamburg, Germany) and $3,3^{\prime}$ diaminobenzidine as chromogen. In other experiments for preparing semithin $1-\mu \mathrm{m}$ sections, $40 \mu \mathrm{m}$ thick frozen sections were first made, labeled with immunoperoxidase as described above, fixed with $2 \%$ glutaraldehyde and $1 \% \mathrm{OsO}_{4}$, and embedded in Epon so that $1-\mu \mathrm{m}$ sections could be cut with an ultramicrotome. For postembedding immunogold staining, small pieces of perfusion-fixed kidney were additionally fixed by immersion in the same fixative (4\% paraformaldehyde in PBS) and embedded in LR White resin (London Resin Co. Ltd., Basingstoke, United Kingdom). Thin sections were cut and labeled with cGK II or cGK I antibody (diluted as above for light microscopy) and goat anti-rabbit antibody-coupled gold particles (Amersham Buchler, Braunschweig, Germany) diluted 1:40. Thereafter the sections were treated with $1 \%$ glutaraldehyde, stained with uranyl acetate and lead citrate, and analyzed in an electron microscope (Philips EM 300).

Isolation of nephron segments. The left kidney was perfused with ice cold Hank's modified microdissection solution (in mM: $137 \mathrm{NaCl}$, $5 \mathrm{KCl}, 0.8 \mathrm{MgSO}_{4}, 0.34 \mathrm{H}_{2} \mathrm{PO}_{4}, 1 \mathrm{MgCl}_{2}, 1 \mathrm{CaCl}_{2}, 4 \mathrm{NaHCO}_{3}, 10$ sodium acetate, 5 D-glucose, 20 Hepes, and $1 \mathrm{mg} / \mathrm{ml} \mathrm{BSA}$ ) and was subsequently perfused with collagenase $(1 \mathrm{mg} / \mathrm{ml})$ dissolved in microdissection solution. Thin pyramids cut along the corticomedullary axis were incubated at $35^{\circ} \mathrm{C}$ for $25 \mathrm{~min}$ ( $45 \mathrm{~min}$ for microdissection of inner medulla) in aerated microdissection solution containing $1 \mathrm{mg} / \mathrm{ml}$ collagenase, then thoroughly rinsed in ice-cold microdissection solution and kept at $4^{\circ} \mathrm{C}$. Microdissection was performed as described previously (19) to isolate glomeruli with afferent arterioles (AA), proximal convoluted tubule (PCT), proximal straight tubule (PST), descending thin limb (DTL), ATL, thick ascending limb (TAL), and cortical (CCD) and inner medullary (IMCD) collecting ducts. Pools consisting of identical types of tubules $(10-40 \mathrm{~mm})$ or $50-100$ glomeruli (400 for Western blot samples) were washed free of contaminating cells or debris and either transferred into denaturing solution for RNA isolation (see below) or were washed free from BSA and transferred into stop solution $(200 \mathrm{mM}$ TrisHCl, $6 \%$ SDS, $15 \%$ glycerin, $\mathrm{pH}$ 6.7) for analysis by Western blots.

$R N A$ extraction from isolated nephron segments. Isolated nephron segments were transferred into $400 \mu$ l of denaturing solution $(4 \mathrm{M}$ guanidinium thiocyanate, $25 \mathrm{mM}$ sodium citrate, $\mathrm{pH} 7.0,0.5 \%$ sarcosyl, $0.1 \mathrm{M} \beta$-mercaptoethanol, and $15 \mu \mathrm{g}$ of yeast tRNA), and total RNA was extracted using a microadaptation (19) of the guanidinium thiocyanate-phenol-chloroform method (18).

Reverse transcription (RT)-PCR. RT was performed using a kit from Life Technologies (Gibco BRL) and either oligo-dT priming or a gene-specific downstream primer. For cDNA amplification, the primers used were 5'-CCGAGGGTAGACTGGAGGTGTT-3' (sense, position 673-694 nt) and 5'-GAATGGGGAGGTTGAGGAGAAT-3' (antisense, position 1376-1397 nt) for rat intestinal cGK II (2), 5'-CGGCAAGTTCAACGGCACAGTCA-3' (sense, position 224$246 \mathrm{nt}$ ) and 5'-GGTTTCTCCAGGCGGCATGTCA-3' (antisense, position 799-820 nt) for glyceraldehyde-3-phosphate dehydrogenase (GAPDH) (20), or 5'-GGTTTCCTCAGCCAAGATGTG-3' (sense, position 492-512 nt) and 5'-CCCAGGTAGAAGGAGATGTCG-3' (antisense, position 1016-1036 nt) for rat renin (21). The cDNA was submitted to $35 \mathrm{PCR}$ cycles $\left(94^{\circ} \mathrm{C}, 40 \mathrm{~s} ; 56^{\circ} \mathrm{C}, 40 \mathrm{~s}\right.$; and $\left.72^{\circ} \mathrm{C}, 1 \mathrm{~min}\right)$, followed by final elongation for $10 \mathrm{~min}$.

Analysis of PCR products. Samples of PCR products were analyzed by electrophoresis on $1.5 \%$ agarose gels and staining with ethidium bromide. In some cases, the cGK II PCR product was isolated from agarose gels by electroelution with a gene capsule device (WAK-Che-

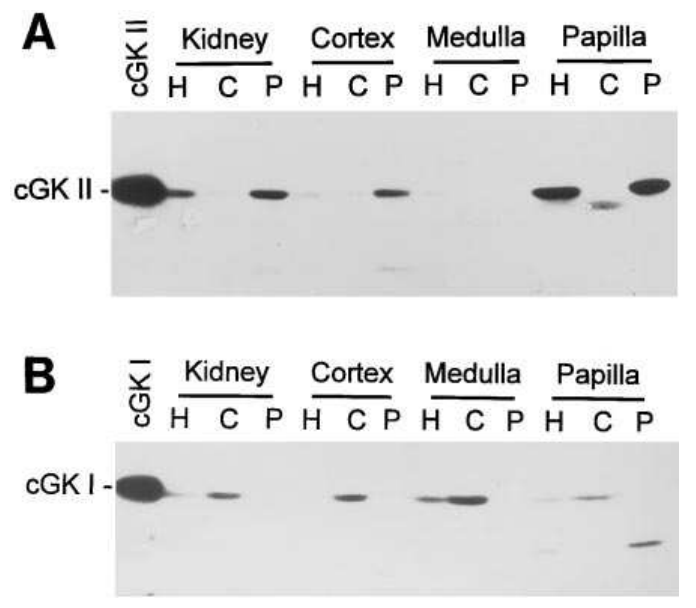

Figure 1. Western blots of endogenous cGK II $(A)$ and cGK I $(B)$ in different zones of rat kidney. cGK II and I were identified by their migrationlike expressed recombinant kinases in Sf9 cell lysates (86 and $76 \mathrm{kD}$, respectively) and were detected using specific antisera and ${ }^{125} \mathrm{I}$-labeled protein A. Shown are samples $(200 \mu \mathrm{g}$ protein each) of whole homogenates $(H)$ as well as supernatant $(C)$ and pellet $(P)$ fractions derived from them by $100,000 \mathrm{~g}$ centrifugation. cGK II was observed in homogenate and membrane fractions, whereas cGK I was observed in homogenate and cytosolic fractions. The blots shown are representative of results from four different experiments. 

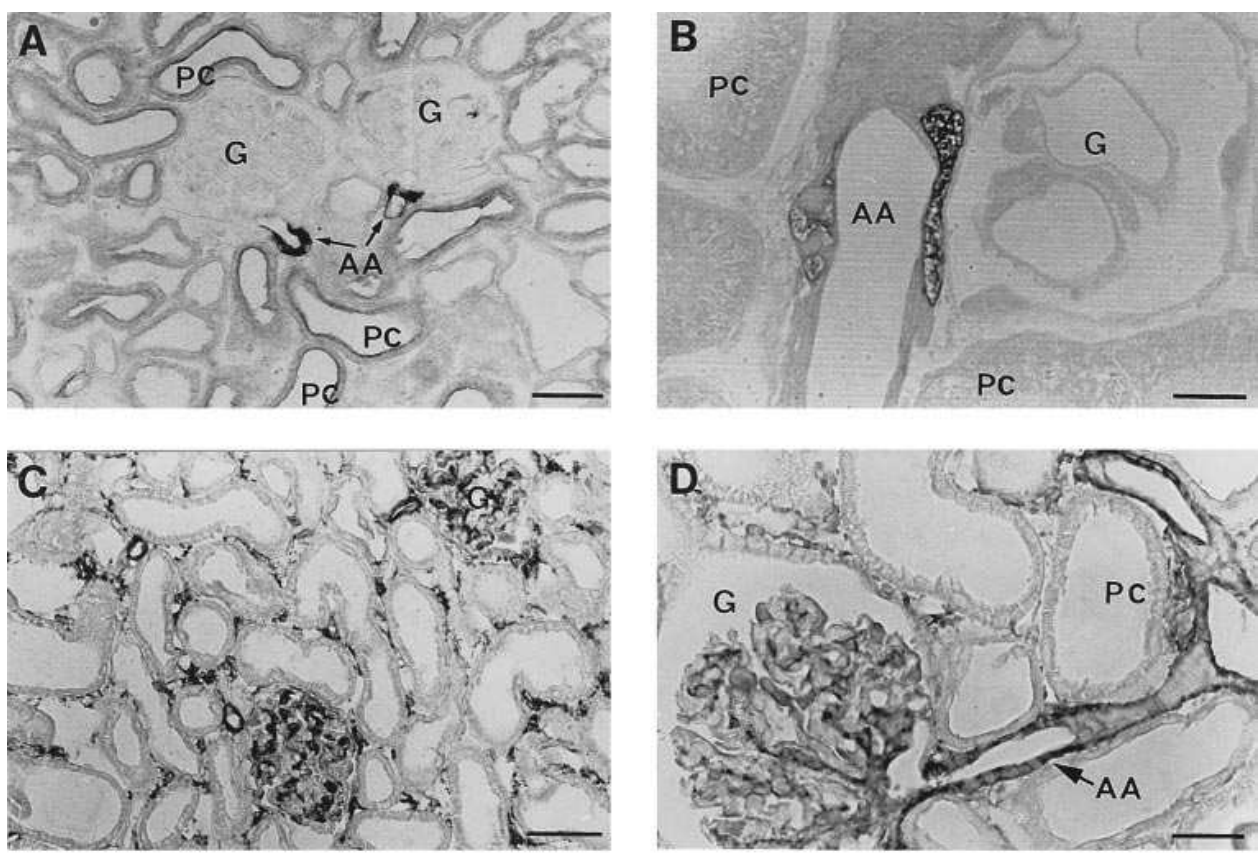

Figure 2. Localization of cGK II ( $A$, $B$, and $E-H)$ and cGK I $(C$ and $D)$ in rat kidney by immunoperoxidase
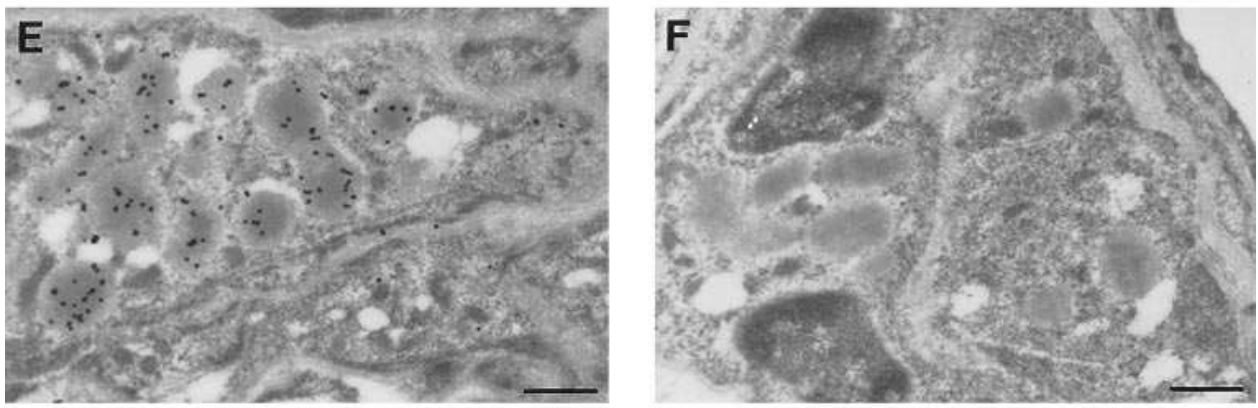
$(A-D, G$, and $H$ ) and immunogold $(E$ and $F$ ) methods. Specific labeling for cGK II was found in afferent arteriole $(A A)$ ( $A$ and $B)$, in juxtaglomerular cells $(E)$, in the inner medullary ascending thin limb ( $A T L$ ) of Henle's loop ( $G$ and $H$ ), and to a lesser extent in the brush border of the proximal convoluted $(P C)$ tubule $(A)$. In $H$, the collecting duct $(C D)$ was unlabeled, and the transition (see arrow) from the descending to the ascending TL was
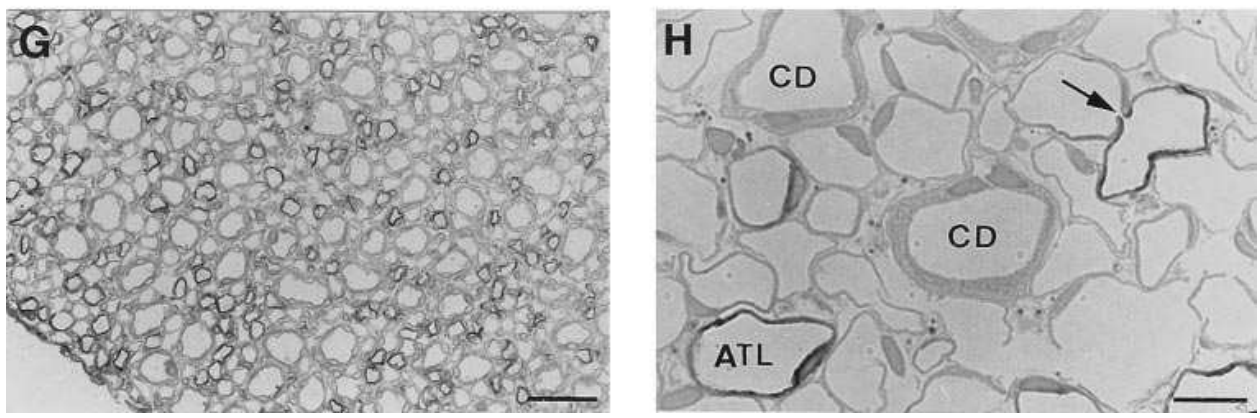
observed. (For identification of ATL and DTL, see Fig. 3.) cGK I $(C$ and $D)$ was not detected in any nephron segment but was found in smooth muscle cells of blood vessels, glomerular $(G)$ mesangium, and interstitial myofibroblasts. Shown are representative results from tissue sections from ten different rats. Bar: $A$ and $C=50 \mu \mathrm{m} ; B$ and $H=10 \mu \mathrm{m} ; D=15 \mu \mathrm{m} ; G=$ $100 \mu \mathrm{m}$; and $E$ and $F=0.5 \mu \mathrm{m}$.

mie, Bad Homburg), and was subcloned (TA-Cloning Kit; Invitrogen Corp., San Diego, CA) and sequenced using fluorescent-labeled vector primers, T7 DNA polymerase, and the ALF Sequencer.

For Southern blot analysis, PCR products separated on agarose gels were denatured, neutralized, blotted onto Hybond- $\mathrm{N}^{+}$filters (Amersham Buchler, Braunschweig, Germany), and hybridized with ${ }^{32} \mathrm{P}$-labeled cGK II DNA made by random primed labeling using pGKII5-5. Subsequently, filters were washed at $68^{\circ} \mathrm{C}$ with $2 \times \mathrm{SSPE} /$ $0.1 \%$ SDS and $0.1 \times$ SSPE/ $0.1 \%$ SDS. In certain experiments, cGK II PCR products were cut from hybridized Southern blot filters and their radioactivity counted.

\section{Results}

Endogenous cGK II and cGK I protein expression in the kidney. On Western blots, cGK II antibody recognized a protein with apparent $M_{\mathrm{r}}$ of $86 \mathrm{kD}$ in whole kidney homogenates and in the membrane pellet fraction after $100,000 \mathrm{~g}$ centrifugation of homogenates. Examination of individual kidney zones demonstrated the presence of cGK II in membrane fractions from kidney cortex and papilla but very little, if any, in the outer medulla (Fig. $1 A$ ). cGK I antibody recognized a protein with apparent $M_{\mathrm{r}}$ of $76 \mathrm{kD}$, primarily detected in the supernatant (cytosolic) fraction after 100,000 $g$ centrifugation of whole kidney homogenates. cGK I was detected in all kidney layers, although the papilla contained the least amount (Fig. $1 B$ ).

Immunocytochemistry was used to obtain a more detailed localization of cGK II in the kidney cortex and papilla (Fig. 2). cGK II immunoreactivity in the cortex was observed within the JG renin-containing cells (Fig. $2 A$ and $B$ ) and to a lesser extent in the brush border of proximal convoluted tubules 

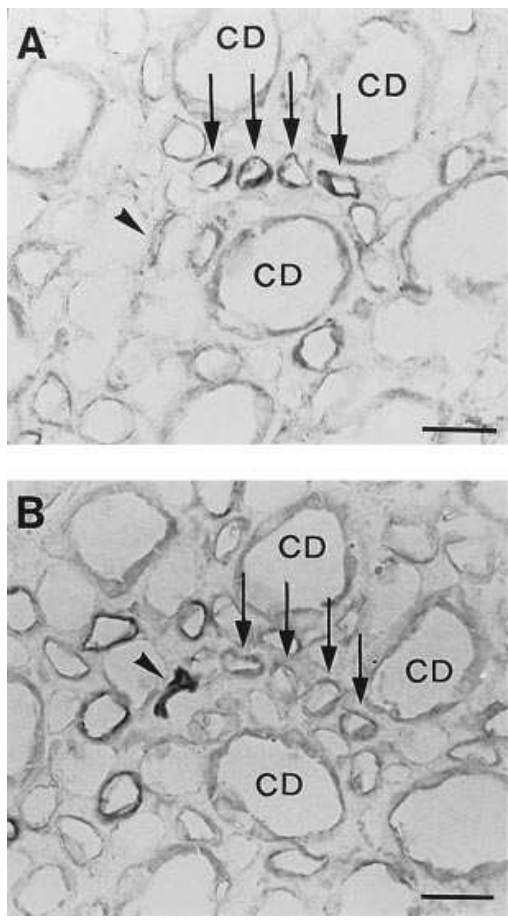

Figure 3. Immunoperoxidase localization of cGK II $(A)$ and the CHIP28 water channel $(B)$ on sequential sections of rat papilla. The same collecting ducts $(C D)$, ATL (arrows), and DTL (arrowhead) are indicated in both sections. Similar results were observed using three different rats. Bar represents $25 \mu \mathrm{m}$.
(Fig. 2 A). This is in sharp contrast to the localization of cGK I which is found in smooth muscle cells of blood vessels, glomerular mesangium, and interstitial myofibroblasts in the cortex (Fig. $2 C$ and $D$ ), and in other kidney layers only in smooth muscle cells of vessels, but in no nephron segments (not shown). Immunogold electron microscopy further defined cGK II immunoreactivity in JG cell renin granules and to a minor extent near the JG cell membrane (Fig. 2 E). Control sections labeled with preimmune serum (Fig. $2 F$ ), as well as omission of primary cGK II antibody or preabsorption of it with cGK II (not shown), failed to exhibit such staining. Furthermore, cGK II antibody did not label peptide granules in other tissues such as pancreas, and cGK I antibody did not label JG cell granules (not shown). Consistent with the lack of cGK II in the outer medulla in Western blots (Fig. $1 A$ ) and the detection of very little cGK II mRNA there on Northern blots (see Fig. 4), cGK II immunoreactivity was not observed in the descending thin limb, thick ascending limb, or medullary collecting duct (not shown). In papilla, strong cGK II immunoreactivity was associated with only one of the two thin limbs of Henle's loop and not with the collecting ducts (Fig. $2 G$ and $H$ ). Higher magnification of the thin limb demonstrated that labeling was in the region of the plasma membrane and that the staining surrounded the nucleus, suggesting that both the apical and basolateral plasma membranes contain cGK II (Fig. $2 H$ ).

Further experiments were performed to distinguish which of the thin limbs of Henle's loop, DTL or ATL, was stained for cGK II. Both papillary thin limbs have very similar morphological features, however they differ functionally. The cells of ATL express high amounts of a kidney-specific chloride channel (CIC-K1) and have an extremely high transepithelial chloride permeability (17). In contrast, the cells of DTL express high amounts of CHIP28 water channels and have a high osmotic water permeability (22). Using antibody against water channels (a generous gift from Dr. P. Agre, Johns Hopkins
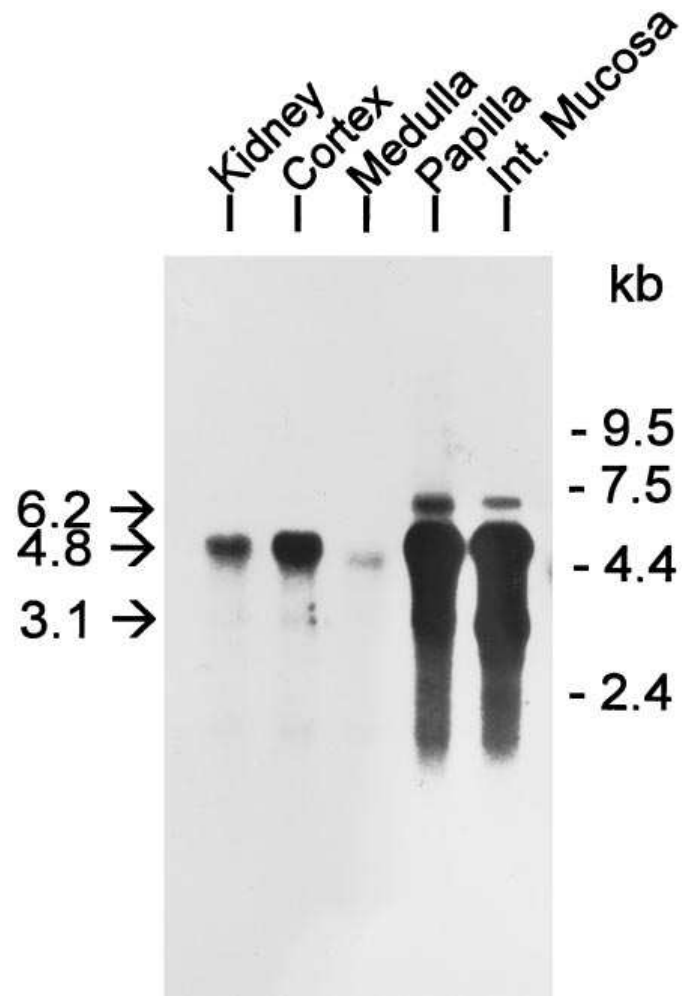

Figure 4. Northern blot analysis of CGK II mRNA isolated from different zones of rat kidney. Poly(A) RNA samples (5 $\mu \mathrm{g}$ each) were hybridized with a ${ }^{32} \mathrm{P}$-labeled cGK II antisense RNA probe. RNA molecular weight standards stained with ethidium bromide (not shown) were used to determine the size of cGK II transcripts $(6.2,4.8$, and $3.1 \mathrm{~kb})$. Intestinal mucosa poly(A) RNA $(0.3 \mu \mathrm{g})$ was used as a positive control. Similar results were obtained in two different experiments.

University, Baltimore, MD) we could show that the staining pattern obtained with cGK II (Fig. $3 A$ ) and CHIP28 (Fig. $3 B$ ) antibodies were different on sequential sections of papilla, indicating that cGK II is localized only in the ATL of Henle's loop.

Localization of cGK II mRNA in kidney zones and nephron segments. Northern blot analysis of cGK II mRNA present in poly(A) RNA samples from different kidney zones and intestinal mucosa is shown in Fig. 4. A major band of $4.8 \mathrm{~kb}$ and minor bands at 6.2 and $3.1 \mathrm{~kb}$, like those found previously in rat intestinal mucosa (2), were observed. Consistent with Western blot data (Fig. $1 A$ ), cGK II mRNA was detected in whole kidney, the cortex, and the papilla (highest amount), but to only a minor extent in the outer medulla. RT-PCR performed with RNA from different kidney zones yielded products of 725 bp which were subcloned, fully sequenced, and found to be identical to nt 673-1397 of cGK II cDNA. Two clones from cortex, and one each from the medulla and papilla, were analyzed.

Microdissected nephron segments were analyzed for cGK II mRNA content by RT-PCR. The PCR product of $725 \mathrm{bp}$ corresponding to cGK II was most abundant in glomerular AA and ATL on ethidium bromide-stained agarose gels (Fig. $5 A$ ) and Southern blots made from the agarose gels (Fig. $5 B$ ). Southern blots revealed additional small signals for cGK II 


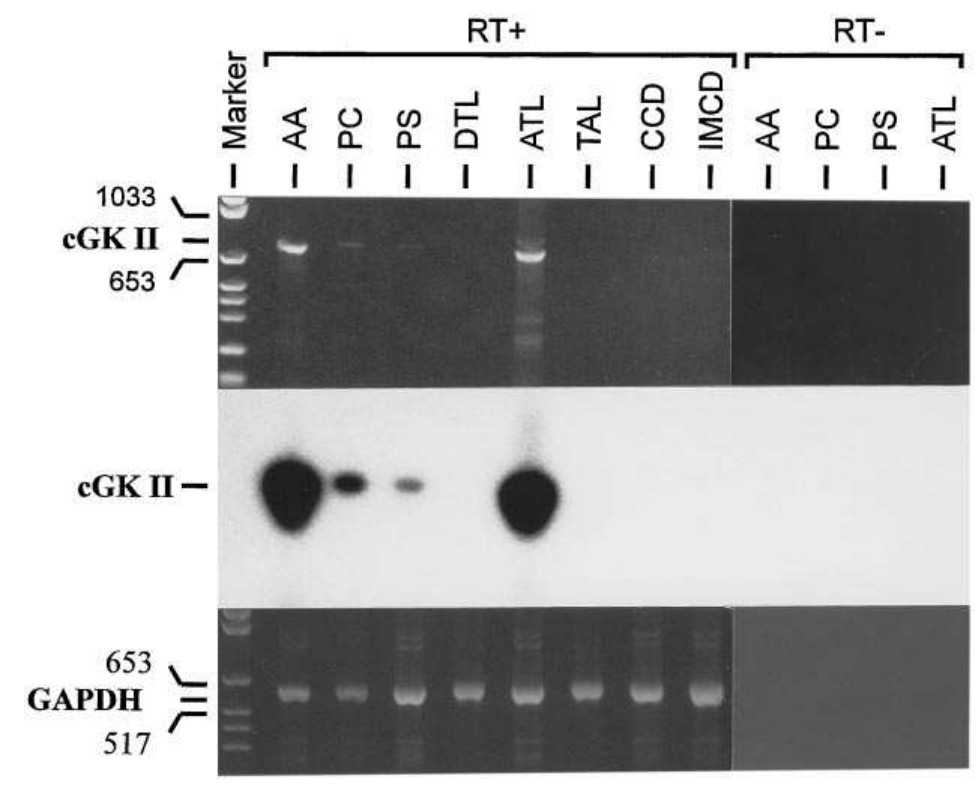

Figure 5. Detection of cGK II mRNA in microdissected nephron segments by RT-PCR. ( $A$ ) Analysis of samples of RT-PCR-derived cGK II cDNA on an ethidium bromide-stained $1.5 \%$ agarose gel. $(B) \mathrm{Au}-$ toradiogram of corresponding samples analyzed on a Southern blot hybridized with a ${ }^{32} \mathrm{P}-$-labeled cGK II

A DNA probe. $(C)$ Detection of RT-PCR-derived GAPDH cDNA on an ethidium bromide-stained $1.5 \%$ agarose gel. DNA molecular weight standards (Marker) and the expected size PCR products ( 725 bp for cGK II and $597 \mathrm{bp}$ for GAPDH) are indicated. PCR was carried out either with $(R T+)$ or without $(R T-)$ reverse transcription. RNA isolated from ei-

B ther five glomeruli with afferent arterioles or from 2 $\mathrm{mm}$ of each nephron segment was used as starting material for RT-PCR reactions. Results are representative of those observed from ten different rats. $A A$, afferent arteriole; $P C$, proximal convoluted tubule; $P S$, proximal straight tubule; $D T L$, descending thin

C limb; $A T L$, ascending thin limb; $T A L$, thick ascending limb; $C C D$, cortical collecting duct; and $I M C D$, inner medullary collecting duct.

mRNA in the proximal convoluted and straight tubules. RTPCR reactions were performed using either $2 \mathrm{~mm}$ of tubule length or five glomeruli with afferent arterioles. Roughly equivalent amounts of GAPDH were amplified in all nephron segments studied (Fig. $5 \mathrm{C}$ ), indicating that similar amounts of tissues were compared in the RT-PCR reactions. When PCR reactions were performed without prior reverse transcription, the cGK II product was not detected, and no other bands were observed in agarose gels or Southern blots (Fig. $5 \mathrm{~A}$, right).

Losartan stimulation of renin and cGK II expression in $J G$ cells. Losartan, a well known specific antagonist of the angiotensin II $\mathrm{AT}_{1}$ receptor, induces JG cell hypertrophy and hyperplasia (23) and increases the expression of renin mRNA in the kidney several fold (24). In our experiments carried out with glomeruli-containing AA, losartan increased the expression of cGK II and renin mRNA (Fig. $6 A-C$, exp.) and cGK II protein (Fig. $6 E$ ) several times in comparison to controls, whereas the GAPDH mRNA abundance (Fig. $6 D$ ) was unchanged. The cGK II mRNA increase was three to fourfold (Fig. $6 F$ ). The right panels of Fig. $6 A-D$ and $F$ show that the abundance of PCR products for cGK II, renin, and GAPDH increased linearly with increasing amounts of starting material (from 1 to 5 glomeruli).

Furthermore, losartan treatment leads to an increase in the renin-producing JG cells in the wall of afferent arterioles (23, 37 ), and such cells also begin to appear in the wall of most efferent arterioles. In our experiments, immunocytochemistry demonstrated that losartan (Fig. $7 \mathrm{~B}$ ) caused an increase in the JG cells expressing cGK II in the AA in comparison to controls (Fig. $7 A$ ), and for the first time cGK II was also observed in cells of the efferent arteriole (not shown). Labeling of sequential sections (not shown) with rat anti-mouse renin and rabbit anti-rat cGK II, respectively, indicated that the induction of renin and cGK II by losartan occurs in the same cells.

Dehydration-induced increase in cGK II expression in kidney papilla. The inner medullary ATL in which we have detected cGK II (Fig. 3) also contains a kidney-specific chloride channel, CIC-K1, whose expression is regulated by dehydration (17). Since the demonstrated function of cGK II in intesti- nal epithelial cells is regulation of chloride channels, in particular CFTR (8), we tested whether the expression of cGK II could also be regulated by dehydration. The expression of cGK II mRNA (Fig. $8 A$ and $B$ ) and protein (Fig. $8 D$ ) in papilla increased several fold in rats deprived of water for $5 \mathrm{~d}$ (exp.) in comparison to controls (contr.). The increase in cGK II mRNA (Fig. $6 E$ ) was about three to fourfold at lower template concentrations for PCR product amplification. Whereas cGK II mRNA increased with water deprivation, mRNA for GAPDH was unchanged (Fig. $8 \mathrm{C}$ ). Dehydration increased the expression of cGK II, and not cGK I (not shown), protein only in papilla and not in kidney cortex (Fig. $8 D$ ).

\section{Discussion}

The renin-angiotensin system (RAS) becomes activated in congestive heart failure (CHF) to maintain cardiac output and tissue perfusion but also worsens heart failure by causing progressive ventricular dilatation (25). Although ANP and cGMP increase with the severity of congestive heart failure (26), their efficacy deteriorates with increasing severity of CHF and RAS activation such that increased vascular resistance and salt and fluid retention ensue (27). Chronic treatment with losartan, an angiotensin II $\mathrm{AT}_{1} \mathrm{R}$ blocker, improves the natriuretic and urinary cGMP excretion responses to ANP in rats with decompensated $\mathrm{CHF}$ (28). In the present study, we have localized one of the major targets of cGMP action, cGK II, within the kidney and, additionally, investigated the effect of losartan on cGK II regulation.

Within the kidney, cGK II is expressed in JG renin-secreting cells, brush border of proximal tubule and in cells of the ATL of Henle's loop. Some ongoing studies focus on the potential role of cGK II in regulation of renin release. However, in general cGMP regulation of renin release seems to be complex and currently not well understood since studies using different cGMP-elevating agents (ANP, NO, and sodium nitroprusside [SNP]), or different cell or tissue systems (isolated perfused rat kidneys, renal cortex slices or cells, isolated JG cells or JG apparatus), have concluded that cGMP can have 


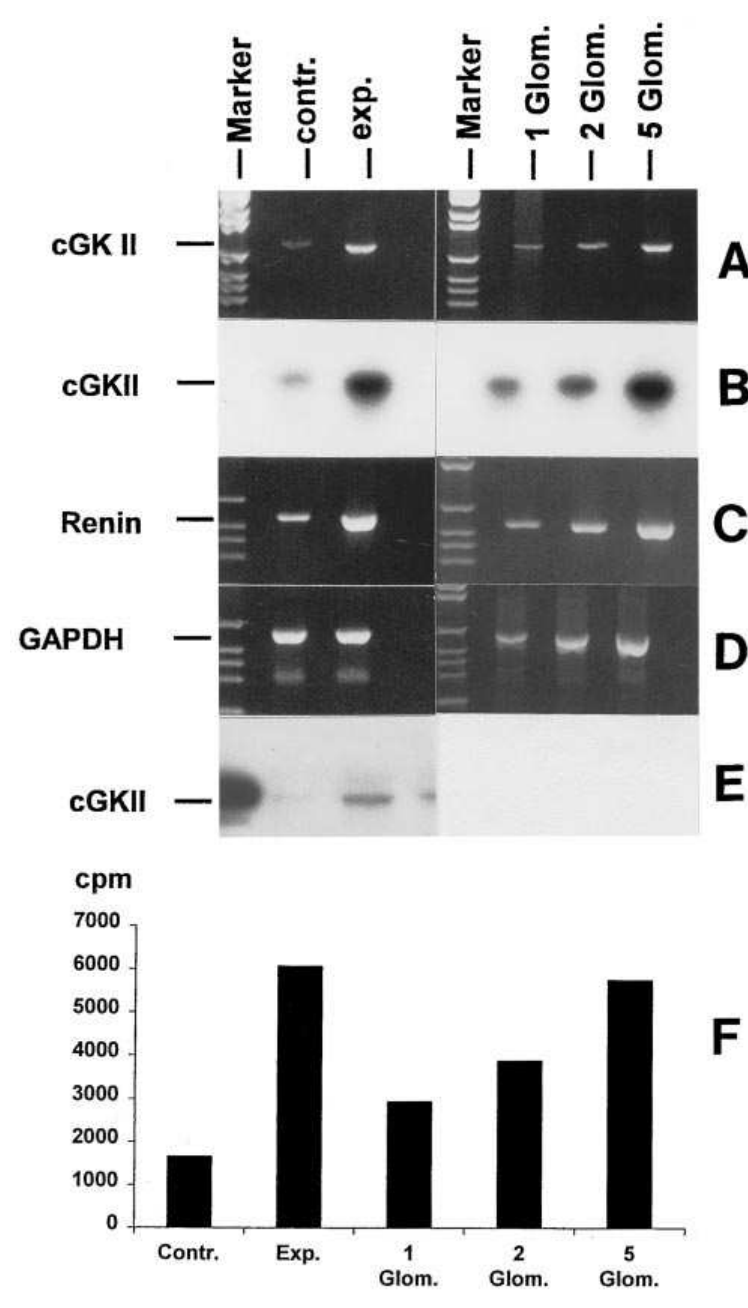

Figure 6. Expression of cGK II mRNA $(A, B$, and $F)$ and protein $(E)$, and renin $(C)$, and GAPDH $(D)$ mRNA, in glomeruli with attached afferent arterioles from untreated controls (contr.) and rats treated with losartan (exp.). ( $A, C$, and $D)$ RT-PCR products shown on ethidium bromide-stained $1.5 \%$ agarose gels. RT-PCR was performed on RNA from 5 glomeruli (contr., exp.; shown at left) and also on RNA from 1, 2, and 5 glomeruli (Glom.; shown at right) from losartan-treated rats $(40 \mathrm{mg} / \mathrm{kg} / \mathrm{d}$ for $5 \mathrm{~d})$. DNA molecular weight standards (Marker) and the expected size PCR products for cGK II (725 bp), renin (545 bp), and GAPDH (597 bp) are indicated. (B) Autoradiogram of corresponding Southern blot of RT-PCR products analyzed using the cGK II hybridization probe described in Fig. 5. $(F)$ Quantitation of the average ${ }^{32} \mathrm{P}$-labeling of the cGK II RT-PCR products on two Southern blots like that shown in $(B) .(E)$ Western blot analysis of cGK II protein in isolated glomeruli containing afferent arterioles (400 glomeruli per sample) from control and losartan (exp.)-treated rats using a specific antibody and ${ }^{125} \mathrm{I}$-protein A. A standard of recombinant cGK II ( $2 \mathrm{ng}$ ) purified from Sf9 cells is shown at left. PCR and Western results are representative of analyses from four different experiments.

stimulatory, inhibitory, or biphasic effects on renin release (10, 29-32). This may imply that there are cGMP-independent effects of some agonists and that there are different cGMP targets of action or different complexities of regulatory feedback systems present in the various cell/tissue preparations. There appear to be opposing forces in the regulation of renin release and those forces predominating under certain conditions may
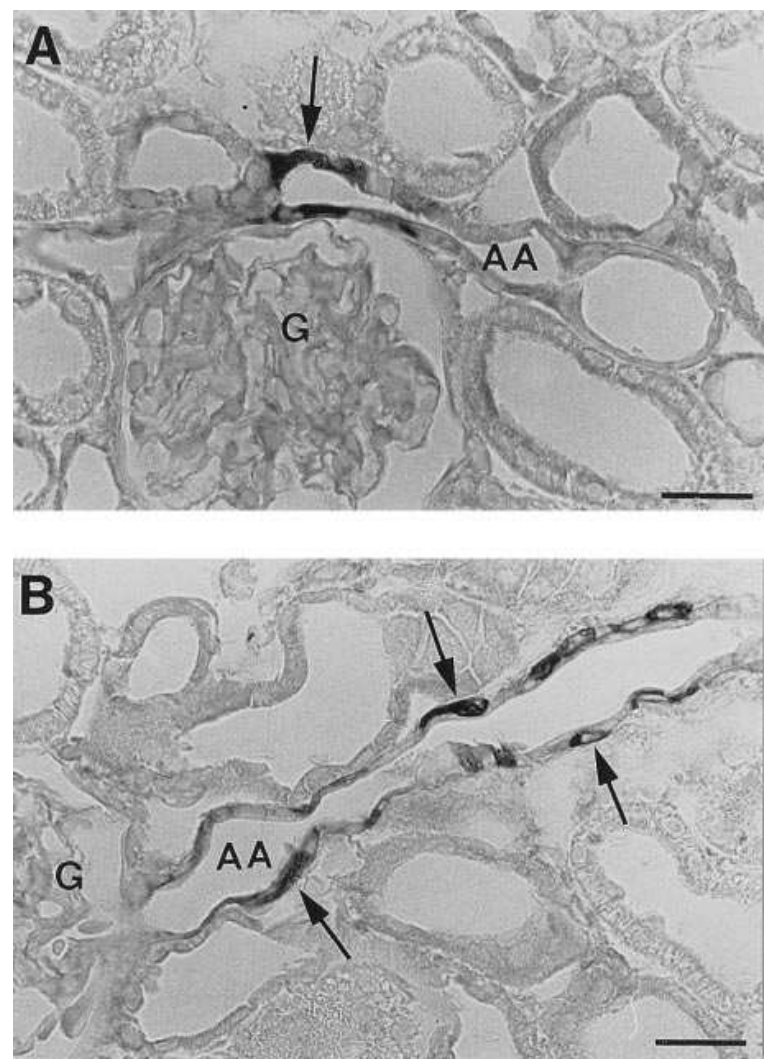

Figure 7. Immunoperoxidase localization of cGK II in afferent arterioles of control $(A)$ and losartan treated $(B)$ rats. $A A$, afferent arteriole; $G$, glomerulus. Arrows in $B$ indicate the increase in JG cells after losartan treatment. Results are representative of those from at least four experiments. Bar represents $25 \mu \mathrm{m}$.

thus determine net release. In JG cells in situ, cGK II was primarily located in renin granules and to some degree associated with the JG cell membrane. Renin granules are not typical endocrine cell secretory granules, nor are they secreted in the typical fashion. They resemble modified lysosomes because they contain some typical lysosomal enzymes and are capable of autophagy and micropinocytosis (33). In contrast to the usual positive effect of $\mathrm{Ca}^{++}$on secretion, $\mathrm{Ca}^{++}$appears inhibitory for renin release. $\mathrm{Ca}^{++}$is suggested to activate a $\mathrm{Cl}^{-}$ channel which promotes $\mathrm{Cl}^{-}$efflux and subsequent osmotic changes resulting in renin granule shrinkage which impedes the granule swelling required for exocytosis of renin (34-36). In intestinal brush border, cGK II promotes $\mathrm{Cl}^{-}$secretion via the CFTR channel $(7,8)$, therefore it is possible that cGK II is involved in the osmotic changes regulating granule swelling and exocytosis. In support of this concept, the losartan experiments indicated coregulation of cGK II and renin. From a regulatory standpoint, it would be reasonable to expect that a pathway for regulating renin release (requiring activation, e.g., by cGMP) should be increased along with stored renin. SNP has also been shown to increase renin mRNA levels (38), suggesting that cGK II could perhaps regulate restoration of renin levels, conceivable since we have previously demonstrated effects of both cGK I (39) and cAK (40) on gene expression in other systems.

cGK II was found both in the brush border of the kidney PT in this report and previously in brush border of the intesti- 


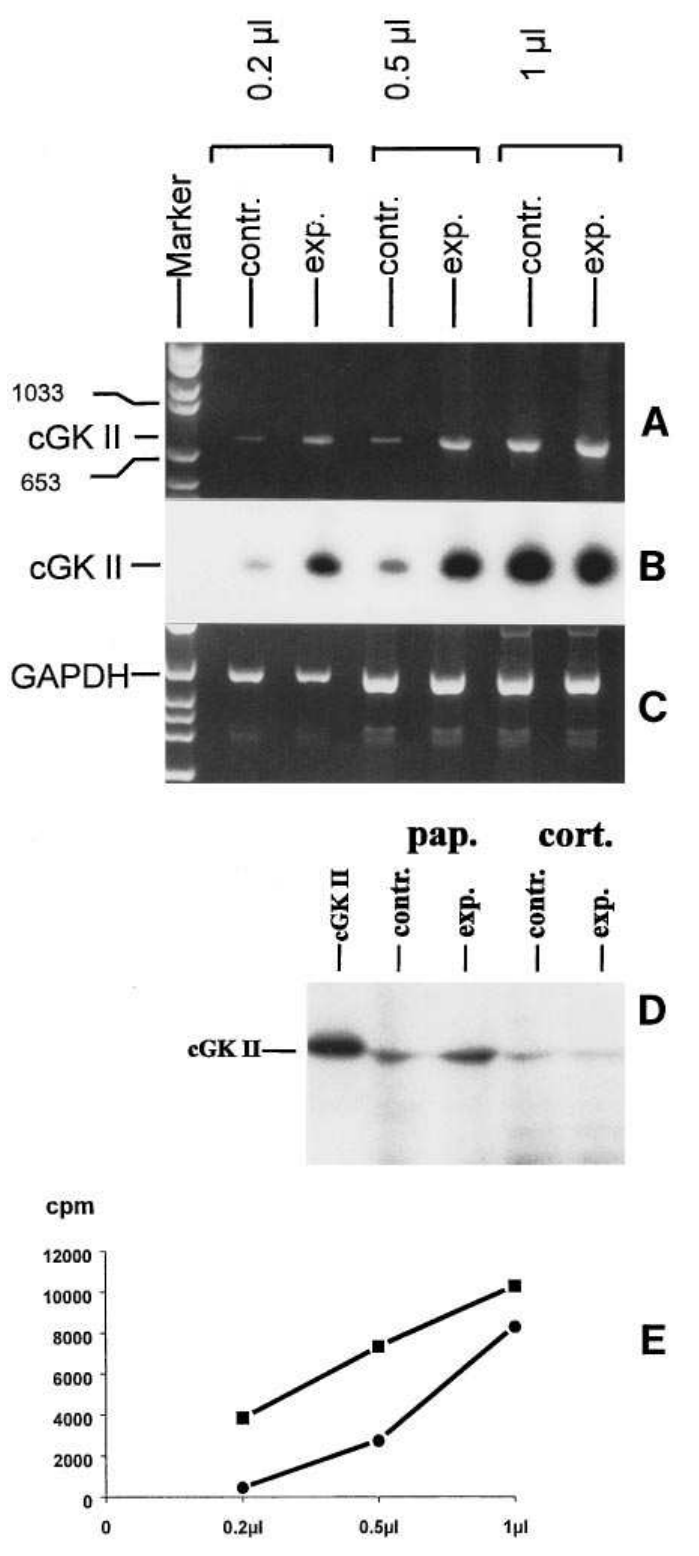

Figure 8. Expression of cGK II mRNA $(A, B$, and $E)$ and protein $(D)$, and GAPDH mRNA $(C)$, in controls (contr.) and rats deprived of water for $5 \mathrm{~d}(\exp$.$) . ( A$ and $C$ ) RT-PCR products shown on ethidium bromide-stained $1.5 \%$ agarose gels. The same amount of total RNA $(2 \mu \mathrm{g})$ isolated from papilla of control and experimental rats was used for RT carried out in a final vol of $20 \mu \mathrm{l}$ from which aliquots $(0.2,0.5$, and $1 \mu \mathrm{l}$, as shown) were removed for PCR. The difference in cGK II mRNA between controls and experimentals $(A)$ was more prominent at lower PCR template concentrations. DNA molecular weight standards (Marker) and expected size PCR products (725 bp for cGK II and $597 \mathrm{bp}$ for GAPDH) are indicated. (B) Autoradiogram of corresponding Southern blot of RT-PCR products analyzed using the hybridization probe described in Fig. 5. (E) Quantitation of the average ${ }^{32} \mathrm{P}$-labeling of the cGK II RT-PCR products on two Southern blots like that shown in $(B)$ for controls $(-)$ and experimentals $(\boldsymbol{\square}) .(D)$ Western blot analysis of cGK II protein in papilla and cortex of control and water-deprived rats. Tissue samples (30 $\mu \mathrm{g}$ protein each) and a standard of recombinant cGK II ( $2 \mathrm{ng}$, shown at left) purified from Sf9 cells were analyzed using a specific antibody and

${ }^{125}$ I-protein A. PCR and Western results are representative of analyses from four different experiments. nal mucosa (7), regions specialized for ion transport and absorption. The level of cGK II in PT appeared to be substantially less than that found in intestinal enterocytes (7), JG cells or ATL, however the PT does contain cGMP signal transduction pathways and examples of cGMP-regulated ion transport which may involve cGK II. A large amount of soluble guanylyl cyclase is expressed in the proximal convoluted and straight tubules (41). ANP, which acts through a transmembrane receptor guanylyl cyclase, stimulated cGMP levels mostly in glomeruli and the IMCD, somewhat less in the inner medullary thin limbs, but to a much lower extent in the proximal convoluted and straight tubules of microdissected rat kidneys (42). However, the full repertoire of activators of cGMP in the kidney, which no doubt include also urodilatin and uroguanylin, etc. (43), and their locations are not known. ANP and cGMP do, however, inhibit angiotensin-stimulated proximal tubule sodium and water reabsorption (44), an effect recently shown to be blocked by a cGK inhibitor (45). Also a portion of the effects of induction of NO synthase in mouse proximal tubule by lipopolysaccharide and interferon- $\gamma$ were shown to be mediated by cGMP inhibition of a basolateral $\mathrm{Na}^{+} / \mathrm{K}^{+}$-ATPase (46). cGMP activation of a PCT apical membrane $\mathrm{Cl}^{-}$channel has been reported which could inhibit paracellular reabsorption of cations, however this effect was apparently insensitive to protein kinase inhibition (47).

Neither cGK II nor cGK I were detected in the IMCD despite the fact that ANP has its greatest effect on cGMP stimulation in that area (42) and that ANP inhibits net $\mathrm{Na}^{+}$and water reabsorption in the collecting duct (9). In the IMCD, cGMP inhibited the opening probability of an amiloride-sensitive $\mathrm{Na}^{+}$channel apparently by both a direct effect on the channel and by an independent effect on exogenous cGK I exposed to the channel (48). There is also recent evidence that cGK activates a cortical collecting duct basolateral $\mathrm{K}^{+}$channel which is necessary for maximal $\mathrm{Na}^{+}$reabsorption (49). Our results show that neither cGK I nor cGK II are endogenously present in any detectable amount in CCD or IMCD, suggesting that cGMP effects in this nephron segment may be predominantly carried out by other mediators.

Of all kidney zones, the papilla, in which cGK II was localized to the ascending thin limb of Henle's loop, contained the greatest amount of cGK II mRNA and protein. After glomeruli and IMCD, the thin limbs contain the next largest amount of ANP receptor mRNA and ANP stimulation of cGMP (50, 42), but only small amounts of soluble guanylyl cyclase (41). The ATL strongly reabsorbs $\mathrm{NaCl}$ and is impermeable to water. Whereas $\mathrm{Na}^{+}$is reabsorbed by a paracellular shunt pathway, $\mathrm{Cl}^{-}$is reabsorbed via $\mathrm{Cl}^{-}$channels in the luminal and basolateral membranes of the ATL cells. Vasopressin has been shown to increase cAMP and stimulate this $\mathrm{Cl}^{-}$transport (51); however no effects of cGMP have as yet been reported. Recently, a kidney-specific $\mathrm{Cl}^{-}$channel $(\mathrm{ClC}-\mathrm{K} 1)$ was cloned (17), localized to the ATL (52), and shown to be increased by dehydration (17). cGK II mRNA and protein which are also found in ATL demonstrated the same induction by dehydration, implying a possible common regulation and function of cGK II and ClC-K1.

Previously, the effect of ANP to increase glomerular filtration rate could be accounted for by the localization of cGK I, however other effects of ANP on tubular function could not. The discovery of cGK II in kidney and the demonstration of its distribution in juxtaglomerular cells, proximal tubule, and as- 
cending thin limb suggest a role for cGK II in mediation of the effects of ANP and other cGMP-elevating substances in some of these regions. Increase of cGK II by losartan, which promotes renin expression, and by dehydration, which increases $\mathrm{ClC}-\mathrm{K} 1$ expression, suggests a potential functional involvement of cGK II in these processes.

\section{Acknowledgments}

We thank Monika Rex-Haffner and Andrea Jahn for excellent technical assistance, Jean-Marc Elalouf (Saclay, France) for helping with RT-PCR in isolated nephron segments, and Michael Zimmer (Würzburg) for helping define PCR primers.

This work was supported by the Deutsche Forschungsgemeinschaft (SFB 355) and the Ernst and Hedda Wollheim Stiftung.

\section{References}

1. Schmidt, H.H.H.W., S.M. Lohmann, and U. Walter. 1993. The nitric oxide and cGMP signal transduction system: regulation and mechanism of action. Biochim. Biophys. Acta. 1178:153-175.

2. Jarchau, T., C. Häusler, T. Markert, D. Pöhler, J. Vandekerckhove, H.R. De Jonge, S.M. Lohmann, and U. Walter. 1994. Cloning, expression, and in situ localization of rat intestinal cGMP-dependent protein kinase II. Proc. Natl. Acad. Sci. USA. 91:9426-9430.

3. Butt, E., J. Geiger, T. Jarchau, S.M. Lohmann, and U. Walter. 1993. The cGMP-dependent protein kinase-Gene, protein, and function. Neurochem. Res. 18:27-42.

4. Cornwell, T.L., and T.M. Lincoln. 1989. Regulation of intracellular $\mathrm{Ca}^{2+}$ levels in cultured vascular smooth muscle cells. J. Biol. Chem. 264:1146-1155.

5. Eigenthaler, M., H. Ullrich, J. Geiger, K. Horstrup, P. Hönig-Liedl, D. Wiebecke, and U. Walter. 1993. Defective nitrovasodilator-stimulated protein phosphorylation and calcium regulation in cGMP-dependent protein kinasedeficient human platelets of chronic myelocytic leukemia. J. Biol. Chem. 268: 13526-13531.

6. Draijer, R., A.B. Vaandrager, C. Nolte, H.R. de Jonge, U. Walter, and V.W.M. van Hinsbergh. 1995. Expression of cGMP-dependent protein kinase I and phosphorylation of its substrate, vasodilator-stimulated phosphoprotein, in human endothelial cells of different origin. Circ. Res. 77:897-905.

7. Markert, T., A.B. Vaandrager, S. Gambaryan, D. Pöhler, C. Häusler, U. Walter, H.R. De Jonge, T. Jarchau, and S.M. Lohmann. 1995. Endogenous expression of type II cGMP-dependent protein kinase mRNA and protein in rat intestine: implications for cystic fibrosis transmembrane conductance regulator. J. Clin. Invest. 96:822-830.

8. French, P.J., J. Bijam, M. Edixhoven, A.B. Vaandrager, B.J. Scholte, S.M. Lohman, A.C. Nairn, and H.R. de Jonge. 1995. Isotype-specific activation of cystic fibrosis transmembrane conductance regulator-chloride channels by cGMP-dependent protein kinase II. J. Biol. Chem. 270:26626-26631.

9. Ballermann, B.J., and M.L. Zeidel. 1992. Atrial natriuretic hormone. In The Kidney: Physiology and Pathphysiology, second edition. D.W. Seldin and G. Giebisch, editors. Raven Press, Ltd., New York. 1843-1884.

10. Schricker, K., and A. Kurtz. 1993. Liberators of NO exert a dual effect on renin secretion from isolated mouse renal juxtaglomerular cells. Am. J. Physiol. 265:F180-F186.

11. Wilcox, C.S., W.J. Welch, F. Murad, S.S. Gross, G. Taylor, R. Levi, and H.H.H.W. Schmidt. 1992. Nitric oxide synthase in macula densa regulates glomerular capillary pressure. Proc. Natl. Acad. Sci. USA. 89:11993-11997.

12. Kurtz, A., R. Della Bruna, J. Pfeilschifter, R. Taugner, and C. Bauer. 1986. Atrial natriuretic peptide inhibits renin release from juxtaglomerular cells by a cGMP-mediated process. Proc. Natl. Acad. Sci. USA. 83:4769-4773.

13. Wada, A., T. Tsutamoto, Y. Matsuda, and M. Kinoshita. 1994. Cardiorenal and neurohumoral effects of endogenous atrial natriuretic peptide in dogs with severe congestive heart failure using a specific antagonist for guanylate cyclase-coupled receptors. Circulation. 89:2232-2240.

14. Biel, M., X. Zong, and F. Hofmann. 1995. Molecular diversity of cyclic nucleotide-gated cation channels. Naunyn-Schmiedebergs Arch. Pharmacol. 353:1-10.

15. Reinhardt, R.R., E. Chin, J. Zhou, M. Taira, T. Murata, V.C. Manganiello, and C.A. Bondy. 1995. Distinctive anatomical patterns of gene expression for cGMP-inhibited cyclic nucleotide phosphodiesterases. J. Clin. Invest. 95:1528-1538

16. Joyce, N.C., P. DeCamilli, S.M. Lohmann, and U. Walter. 1986. cGMPdependent protein kinase is present in high concentrations in contractile cells of the kidney vasculature. J. Cycl. Nucl. Prot. Phosphor. Res. 11:191-198.

17. Uchida, S., S. Sasaki, T. Furukawa, M. Hiraoka, T. Imai, Y. Hirata, and F. Marumo. 1993. Molecular cloning of a chloride channel that is regulated by dehydration and expressed predominantly in kidney medulla. J. Biol. Chem.
268:3821-3824.

18. Chomczynski, P., and N. Sacchi. 1987. Single-step method of RNA isolation by acid guanidinium-thiocyanate-phenol-chloroform extraction. Anal. Biochem. 162:156-159.

19. Elalouf, J.-M., J.-M. Buhler, C. Tessiot, A.-C. Belanger, I. Dublineau, and C. de Rouffignac. 1993. Predominant expression of $\beta_{1}$-adrenergic receptor in the thick ascending limb of rat kidney. J. Clin. Invest. 91:264-272.

20. Fort, P., L. Marty, M. Piechaczyk, S. El Sabrouty, Ch. Dani, Ph. Jeanteur, and J.M. Blanchard. 1985. Various rat adult tissues express only one major mRNA species from the glyceraldehyde-3-phosphate-dehydrogenase multigenic family. Nucleic Acids Res. 13:1431-1442.

21. Tada, M., A. Fukamizu, M.S. Seo, S. Takahashi, and K. Murakami. 1988. Nucleotide sequence of rat renin cDNA. Nucleic Acids Res. 16:3576.

22. Nielsen, S., B.L. Smith, E.I. Christensen, M.A. Knepper, and P. Agre. 1993. CHIP28 water channels are localized in constitutively water-permeable segments of the nephron. J. Cell Biol. 120:371-383.

23. Owen, R.A., S. Molon-Noblot, M.F. Hubert, P.K.S. Siegl, R.S. Eydelloth, and K.P. Keenan. 1994. Juxtaglomerular cell hypertrophy and hyperplasia induced in Rhesus monkeys by angiotensin II receptor antagonists. Lab. Invest. 71:543-551.

24. Holmer, S., K.-U. Eckardt, O. Aedtner, M. LeHir, K. Schricker, M. Hamann, K. Götz, G. Riegger, W. Moll, and A. Kurtz. 1993. Which factor mediates reno-renal control of renin gene expression? J. Hypertens. 11:1011-1019.

25. Kang, P.M., A.J. Landau, R.T. Eberhardt, and W.H. Frishman. 1994 Angiotensin II receptor antagonists: a new approach to blockade of the reninangiotensin system. Am. Heart J. 127:1388-1401.

26. Jakob, G., J. Mair, M. Pichler, and B. Puschendorf. 1995. Ergometric exercise testing and sensitivity of cyclic guanosine $3^{\prime}, 5^{\prime}$-monophosphate (cGMP) in diagnosing asymptomatic left ventricular dysfunction. Br. Heart J. 73:145150

27. Elsner, D., F. Muders, A. Müntze, E.P. Kromer, W.-G. Forssmann, and G.A.J. Riegger. 1995. Efficacy of prolonged infusion of urodilatin [ANP-(95126)] in patients with congestive heart failure. Am Heart J. 129:766-773.

28. Abassi, Z.A., G. Kelly, E. Golomb, H. Klein, and H.R. Keiser. 1994. Losartan improves the natriuretic response to ANF in rats with high-output heart failure. J. Pharm. Exp. Ther. 268:224-230.

29. Schricker, K., T. Ritthaler, B.K. Krämer, and A. Kurtz. 1993. Effect of endothelium-derived relaxing factor on renin secretion from isolated mouse renal juxtaglomerular cells. Acta Physiol. Scand. 149:347-354.

30. Noble, A.R., R.A. Abu-Kishk, M.-A.E.D'Aloia, B.C. Williams, and D.J. Lush. Cyclic GMP-linked pathway for renin secretion. 1994. Kidney Int. 46: 1588-1590.

31. He, X.-R., S.G. Greenberg, J.P. Briggs, and J.B. Schnermann. 1995. Effect of nitric oxide on renin secretion. II. Studies in the perfused juxtaglomerular apparatus. Am. J. Physiol. 268:F953-F959.

32. Greenberg, S.G., X.-R. He, J.B. Schnermann, and J.P. Briggs. 1995. Effect of nitric oxide on renin secretion. I. Studies in isolated juxtaglomerular granular cells. Am. J. Physiol. 268:F948-F952.

33. Reudelhuber, T.L. 1995. Molecular biology of renin. In Molecular Nephrology: Kidney Function in Health and Disease. D. Schlöndorff and J. V. Bonventre, editors. Marcel Dekker, Inc., New York. 71-89.

34. Kurtz, A., and R. Penner. 1989. Angiotensin II induces oscillations of intracellular calcium and blocks anomalous inward rectifying potassium current in mouse renal juxtaglomerular cells. Proc. Natl. Acad. Sci. USA. 86:3423-3427.

35. Kurtz, A. 1989. Cellular Control of renin secretion. Rev. Physiol. Biochem. Pharmacol. 113:1-40.

36. Sigmon, D.H., and J.C.S. Fray. 1991. Chemiosmotic control of renin release from isolated renin granules of rat kidneys. J. Physiol. (Lond.). 436:237256.

37. Schricker, K., I. Hegyi, M. Hamann, B. Kaissling, and A. Kurtz. 1995. Tonic stimulation of renin gene expression by nitric oxide is counteracted by tonic inhibition through angiotensin II. Proc. Natl. Acad. Sci. USA. 92:80068010 .

38. Schricker, K., R. Della Bruna, M. Hamann, and A. Kurtz. 1994. Endothelium derived relaxing factor is involved in the pressure control of renin gene expression in the kidney. Pflugers Arch.-Eur. J. Physiol. 428:261-268.

39. Gudi, T., I. Huvar, M. Meinecke, S.M. Lohmann, G.R. Boss, and R.B. Pilz. 1996. Regulation of gene expression by cGMP-dependent protein kinase: transactivation of the c-fos promoter. J. Biol. Chem. 271:4597-4600.

40. Büchler, W., M. Meinecke, T. Chakraborty, T. Jahnsen, U. Walter, and S.M. Lohmann. 1990. Regulation of gene expression by transfected subunits of cAMP-dependent protein kinase. Eur. J. Biochem. 188:253-259.

41. Terada, Y., K. Tomita, H. Nonoguchi, and F. Marumo. 1992. Polymerase chain reaction localization of constitutive nitric oxide synthase and soluble guanylate cyclase messenger RNAs in microdissected rat nephron segments. J. Clin. Invest. 90:659-665.

42. Nonoguchi, H., M.A. Knepper, and V.C. Manganiello. 1987. Effect of atrial natriuretic factor on cyclic guanosine monophosphate and cyclic adenosine monophosphate accumulation in microdissected nephron segments from rats. J. Clin. Invest. 79:500-507.

43. Hess, R., M. Kuhn, P. Schulz-Knappe, M. Raida, M. Fuchs, J. Klodt, K. Adermann, V. Kaever, Y. Cetin, and W.-G. Forssmann. 1995. GCAP II: isola- 
tion and characterization of the circulating form of human uroguanylin. FEBS Lett. 374:34-38.

44. Garvin, J.L. 1989. Inhibition of $\mathbf{J}_{\mathrm{v}}$ by ANF in rat proximal straight tubules requires angiotensin. Am. J. Physiol. 257:F907-F911.

45. Garcia, N.H., and J.L. Garvin. 1995. ANF and angiotensin II interact via kinases in the proximal straight tubule. Am. J. Physiol. 268:F730-F735.

46. Guzman, N.J., M.-Z. Fang, S.-S. Tang, J.R. Igelfinger, and L.C. Garg. 1995. Autocrine inhibition of $\mathrm{Na}^{+} / \mathrm{K}^{+}$-ATPase by nitric oxide in mouse proximal tubule epithelial cells. J. Clin. Invest. 95:2083-2088.

47. Darvish, N., J. Winaver, and D. Dagan. 1995. A novel cGMP-activated $\mathrm{Cl}^{-}$channel in renal proximal tubules. Am. J. Physiol. 268:F323-F329.

48. Light, D.B., J.D. Corbin, and B.A. Stanton. 1990. Dual ion-channel regulation by cyclic GMP and cyclic GMP-dependent protein kinase. Nature
(Lond.). 344:336-339.

49. Hirsch, J., and E. Schlatter. 1995. $\mathrm{K}^{+}$channels in the basolateral membrane of rat cortical collecting duct are regulated by a cGMP-dependent protein kinase. Pflugers Arch.-Eur. J. Physiol. 429:338-344.

50. Terada, Y., T. Moriyama, B.M. Martin, M.A. Knepper, and A. GarciaPerez. 1991. RT-PCR microlocalization of mRNA for guanylyl cyclase-coupled ANF receptor in rat kidney. Am. J. Physiol. 261:F1080-F1087.

51. Takahashi, N., Y. Kondo, O. Ito, Y. Igarashi, K. Omata, and K. Abe. 1995. Vasopressin stimulates $\mathrm{Cl}^{-}$transport in ascending thin limb of Henle's loop in hamster. J. Clin. Invest. 95:1623-1627.

52. Uchida, S., S. Sasaki, K. Nitta, K. Uchida, S. Horita, H. Nihei, and F. Marumo. 1995. Localization and functional characterization of rat kidney-specific chloride channel, CIC-K1. J. Clin. Invest. 95:104-113. 